\title{
Analysis of Initial Teacher Training for the European Area: A Key Instrument of Social Transformation
}

\section{Maria del Carmen Pegalajar Palomino ${ }^{1}$ \\ Marta Medina-Garcia ${ }^{2}$ (i) \\ Lina Higueras-Rodriguez ${ }^{3}$}

University of Jaen, Department of Pedagogy, Spain

Email:mopegala@ujaen.es

${ }_{2, s}^{2 .}$ University of Almeria, Department of Education, Spain.

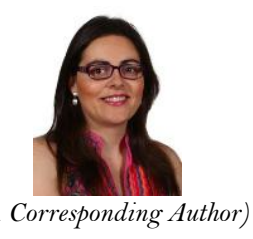

( Corresponding Author)

Abstract

University plays a vital role in the social development of students, and, in line with this premise, the main foundations for the creation of the European Higher Education Area are based on the social perspective for its promotion. The introduction of the Spanish university system into the European Higher Education Area has had an impact on initial teacher training. In order to maintain a balance from the social perspective, this work analyses the student's perception of a bachelor's degree in early childhood education and primary education and a master's in secondary education on the implications of the European convergence process for their initial training. It is a descriptive study that uses an "ad hoc" scale as an instrument for data collection, addressed to students from two Spanish universities $(n=682)$. Results show the positive evaluation of the student towards the practicum, understood as a complement to their academic training, as well as the coherence between the theoretical and practical contents in the different subjects, among other aspects. However, it also criticizes the development of subjects taught by several professors, as well as the lack of information disseminated by the university on the implications that this European process has generated in the teaching-learning process. These perceptions are more favorable in master's students than in undergraduate students. This allows the identification of the potentialities and limitations of the European process for the initial teacher training.

Keywords: Higher education, university student, curriculum, quality of education, European higher education area, degree, master's.

Citation | Maria del Carmen Pegalajar Palomino; Marta MedinaGarcia; Lina Higueras-Rodriguez (2020). Analysis of Initial Teacher Training for the European Area: A Key Instrument of Social Transformation. Journal of Education and e-Learning Research, $7(3): 277-284$.

History:

Received: 22 May 2020

Revised: 16 July 2020

Accepted: 10 August 2020

Published: 19 August 2020

Licensed: This work is licensed under a Creative Commons

Attribution 3.0 License $(\mathrm{cc}) \mathbf{E Y}$

Publisher: Asian Online Journal Publishing Group
Acknowledgement: All authors contributed to the conception and design of the study.

Funding: This study received no specific financial support

Competing Interests: The authors declare that they have no conflict of interests.

Transparency: The authors confirm that the manuscript is an honest, accurate, and transparent account of the study was reported; that no vital features of the study have been omitted; and that any discrepancies from the study as planned have been explained.

Ethical: This study follows all ethical practices during writing.

\section{Contents}

1. Introduction

Materials and Methods

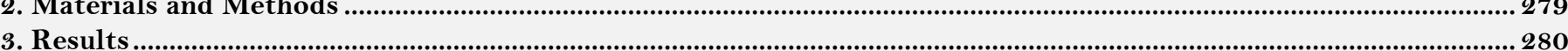

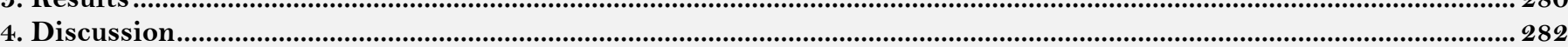

5. Conclusion ...

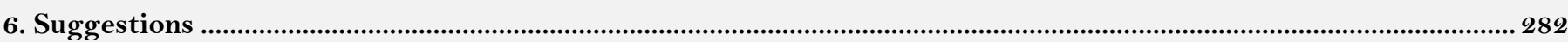

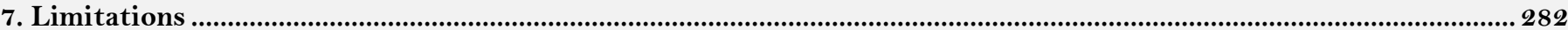

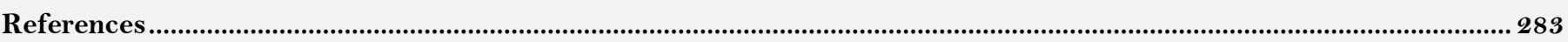




\section{Contribution of this paper to the literature}

This paper analyses the student's perception of the bachelor's degree in early childhood education and primary education and the master's in secondary education on the implications of the European convergence process for their initial training. This favors student reflections on the meaning and scope of this reform in university education as a key element of social transformation.

\section{Introduction}

The continuous transformations that affect society cause identity problems for teachers, generating significant challenges that they must face. Social change has transformed the teaching profession, as well as its image and the value we place on it Rivas, (2016). Social transformations act in the educational context, generating a critique and revision of curricular content. As Vaillant (2010) mentions, everything leads to the need to modify methodologies and working conditions in educational centers. In order to respond to social demands and changes, teacher training must be the key. Initial training is required that is adapted to various changes and that coaches teachers so they are prepared for pedagogical practice (Esia-Donkoh \& Baffoe, 2018; Quero, 2006).

From this social perspective, that education in general terms implies and carries with it, universities also echo these circumstances and play a fundamental role as the driving force of society, given their importance and impact on different spheres of social welfare (Doña, 2014).

In view of these circumstances, higher education is immersed in a major process of change that requires its modernization, adaptation, and ability to overcome economic, academic, or social challenges such as the European Higher Education Area (Doña, 2014). The Bologna process, initiated in the university system 20 years ago, has allowed the implementation of important changes for Higher Education at European and World levels (Dienel, 2019). In total, 48 States are integrated within the European Higher Education Area; this facilitates the design of a system of educational cooperation at the international level (Klemenčič, 2019) through academic and research exchange between countries (Oosterlinck, 2013).

The foundations for the creation of the European Higher Education Area are found in the process of social transformation (Jarvis, 2006). Hence, its background is located on the one hand in the role of educational institutions to promote democratic societies, thereby strengthening social cohesion, and on the other hand, in its value to ensure equal opportunities and achieve quality education for all people (Alonso-Sáez \& Arandia-Loroño, 2017). All this under the proposal of creating a university model that responds to social demands and the needs of change to adapt to the reality of the 21 st century (Cabaco, 2006). This question is perfectly linked to the need to promote a 'European conscience' whose process inevitably passes through the educational sphere to generate a change of mentality as a social and political representation of what Europe is Castro, Trujillo, and Merino (2006). This is a fact that is becoming increasingly evident, given the importance of education and training, fundamentally higher education, as an element of the transnational social system (Meyer \& Ramírez, 2002).

A university also contributes to the creation and application of knowledge through its transmission via its social dimension. Therefore, knowledge is key not only to economic growth but also to the growth of other kinds of intangible assets such as social cohesion, sustainability, etc. Mora (2004). In view of this panorama of what the knowledge society means and implies, the European Union's strategy focuses on European education and training systems to address it Castro et al. (2006). Quality is another element to highlight in any educational institution in social terms, as it guarantees social trust and relevance. Therefore, the adaptation of Spanish universities to the European Higher Education Area is a quality process that translates into an improvement in social guarantees, fundamentally through student mobility, which is a key aspect of social construction (Castro et al., 2006).

Furthermore, this reform has important implications for university curricula, affecting the structural organization of degrees, the ordering of subjects, and the design of a new pedagogical model for the development of the teaching-learning process (Galán, 2012). As a result, there has been a massification of university classrooms with new students who are moving away from the traditional teaching model, the development of a training proposal that progressively acquires an international character, the incorporation of the concept of "lifelong learning" (Montes \& Suárez, 2016), as well as the transformation of some of the assumptions on which the conception of teaching and the construction of identity in university teaching staff are based (Zabalza, 2016).

The traditional teaching model characterized by teacher control for content management and decision-making in student learning is now in the past (Tezci, 2017). This has given rise to a new approach based on the active and responsible role of the student in their learning process (Vallet-Bellmunt, Rivera, Vallet-Bellmunt, \& ValletBelmunt, 2017). In addition, and from this new model, the development of teaching-learning processes from different contexts acquires importance, maintaining spaces of collaboration between the work environment and the researcher (Vazirani, Carmona, Hernaiz, \& Shuali, 2019). This methodological change has meant an improvement in students' qualifications, as well as an increase in their motivation for learning, the interaction between peers, and commitment to study (Mingorance, Granda, Rojas, \& Alemany, 2019; Santos \& Serpa, 2020).

In this process of change and European requirements, Spanish universities have been pioneers in adapting curricula for degrees linked to teacher training (Vallejo \& Molina, 2011). This constitutes the basis of education, as it represents the initial phase for the development of the future citizens of our society (Lüdke \& Scott, 2018). Therefore, and taking into account the duty of the university institution to guarantee the quality of education, it is necessary to continuously and systematically evaluate the changes proposed in this teacher training process; the aim is to detect possible difficulties that may be encountered by each of the agents involved (Radulovíc, Gajic, Spanovic, \& Lungulov, 2019) and, as a consequence, to establish a protocol for improvement.

The review of the literature demonstrates the scarcity of research related to the object of this work in the Spanish context. However, it is worth highlighting some studies that reveal the favorable perception of students towards the new situation in Higher Education (Castano, Capa, Lozano, \& Jiménez, 2007; Otero, Ferro, \& Vila, 2012). The student maintains that the new educational model has allowed the inclusion of new methodologies and didactic resources in the teaching-learning process (highlighting the use of information and communication technologies), enabling greater interaction among equals (Ariza, Quevedo, Bermúdez, \& Buela, 2013; Quevedo, Ariza, \& Buela, 2015). In addition, it considers that it favors autonomous work in students, the development of 
competency-based learning, the modification of the assessment system, the reduction of the teacher-student ratio, as well as the development of personalized attention through tools such as academic tutoring (Rodríguez, 2013). In short, the implementation of this new model allows us to implement changes for a greater and better academic and professional orientation in students (Rodicio, 2010).

However, other research shows the negative assessment of students towards the adaptation of Higher Education to the European process (Coterón, 2012; Expósito Langa, Tomas Miquel, \& Torres Gallardo, 2012). The scarce information provided by the university institution about the European space and its role within the teachinglearning process is questioned (Méndez, 2008), qualifying the information received as negative and, sometimes, distorted (Font-Mayolas \& Masferrer, 2010). In addition, students denounce insufficient dissemination of information on aspects related to mobility and international recognition of their degree studies (Sánchez, 2015), which prevents a more effective implementation of the European Higher Education Area (Leo \& Cubo, 2012).

Student dissatisfaction with the established curriculum does not only involve undergraduate students. Since the implementation of the European Higher Education Area in Spain, official Masters studies have grown in quantity and quality (Hauschildt, Gwosć, Netz, \& Mishra, 2015), so it is also necessary to inquire into their degree of satisfaction with the studies they carry out based on their training experience (Gibbs, 2012; Migdadi \& Baniabdelrahman, 2016; Soilemetzidis, Bennett, \& Leman, 2014). In this sense, Cohen (2012) confirms the positive impact that student satisfaction has on university persistence.

The student of a master's in teacher training in secondary education also criticizes issues such as time organization and the lack of coordination between theoretical and practical contents of the subjects, etc. Hernández and Carrasco (2012). This can be justified, as confirmed by Pérez, Quijano, and Ocaña (2013), to the poor planning and caution with which the adaptation of the Bologna Plan is being carried out in the Spanish university context; it is not encouraging a change in institutional and professional culture according to the times and possibilities of the members of the university community involved in the process.

However, these perceptions are improving as the student gets older and for the one who is studying for the degree in the humanities and social sciences (Pegalajar, 2016). In this sense, the research proposed by Wilkins, Butt, Kratochvil, and Balakrishnan (2016) determines how professional experience is a variable that can favor student commitment and satisfaction towards the studies they carry out, while Xu (2014) explains how the degree of satisfaction for the master's student is associated with contextual variables, such as the type of discipline or field of study.

Thus, the European Higher Education Area requires higher education institutions to assess the quality of training processes. Therefore, this paper analyses the student's perception of the bachelor's degree in early childhood education and primary education and the master's in secondary education about the implications of the European convergence process for their initial training. This favors student reflection on the meaning and scope of this reform in university education as a key element of social transformation.

Thus, and more specifically, the following direct objectives are intended to be met:

- Analyze the student's assessment of the academic restructuring of university education.

- Examine student assessment in terms of teaching planning.

- Study student perceptions of the process of transformation in higher education thanks to European convergence.

- Examine student assessments of higher education in matters related to teaching organization.

- Know the student's estimations about the academic information available for the degree they are studying.

- Examine the student's evaluations on their possibilities of specialization.

- Check whether there are any differences on a statistical level in the assessments made by education students towards the European convergence process according to their bachelor's degree or master's studies.

\section{Materials and methods}

\subsection{Participants}

The population object of this study is composed of university students enrolled in the 4th year of the bachelor's degree in early childhood education and primary education and the university masters in the teaching of compulsory secondary education and high school, professional training and language teaching from two Spanish universities, these being first, the Catholic University of Murcia (privately owned) and second, the Universidad of Jaen (publicly owned).

The selection of the sample responds to an incidental sampling, forming part of the same students who have voluntarily accepted to fill in the scale provided $(n=682)$. The final sample meets the criteria of representativeness, using the formula for populations of less than 100000 subjects, with a confidence level of $95 \%$ and a maximum estimation error of $4 \%$.

With regard to the description of the socio-demographic characteristics of the sample, it should be noted that $40,2 \%$ are men, compared to $59,8 \%$ women. The age of the students is $65,8 \%$ between $20-25$ years old, while $18,3 \%$ of the sample is between $26-30$ years old, $12,9 \%$ is over 31 years old, and, finally, 3,0\% is under 20 years old. Focusing on the studies they are taking, 37,3\% are students in the primary education degree, $36,2 \%$ are enrolled in the early childhood education degree, and, finally, 26,5\% of the students come from the master's in secondary education. Finally, 32,7\% of the sample is studying for a master's in humanities, social and business sciences, $27,5 \%$ in science and technology, 20,3\% in physical activity and sports, 17,5\% in philology and languages, and finally, $2,0 \%$ in the arts.

\subsection{Instrument}

This work uses as a data collection instrument, the "Scale on University Students' Attitudes towards the European Higher Education Area." This instrument, which was developed "ad hoc," aims to assess the higher 
education student's perceptions towards the European convergence process. It is a Likert-type scale with response options ranging from 1 to 5 (with $1=$ total disagreement and $5=$ full agreement), composed of six key factors:

- Factor 1. Academic restructuring in the European Higher Education Area, linked to the analysis of the degree course, curricula, adequacy of teaching guides, quality of university education, etc.

- Factor 2. Teaching planning explores how university teachers take into account their proposal so that the teaching-learning process is developed in the most optimal way possible.

- Factor 3. European convergence in curricula based on the analysis of the process of European change to the new degrees in higher education.

- Factor 4. Teaching organization, which examines questions on the planning and development of the teaching-learning process for quality improvement in higher education.

- Factor 5. Academic information includes questions related to the study of student knowledge towards the degree.

- Factor 6. Specialization of degrees examines the degree of knowledge of the student about their possibilities of specialization in the academic process.

This instrument meets the criteria of reliability and validity of quality (Tezci, 2017). The scale has been validated by a group of experts, specifically ten teachers of didactics and school organizations from various Andalusian universities, with extensive experience in evaluating questionnaires. The considerations of the experts have been taken into account on the initial version of the scale. Then, a pilot test of the instrument has been carried out to a group of third-year students of the bachelor's degree in child education at the University of Jaén ( $\mathrm{n}=50$ ). In this sense, it should be noted that their results were included in the final sample of the study.

The Barlett's sphericity test shows a value of chi-square $=2149,940(\mathrm{p}=, 000)$, demonstrating that the data matrix obtained is suitable to carry out the factorial analysis of the scale. In addition, the Kaiser-Meyer-Olkin sample adequacy index $(\mathrm{KMO})=, 72$, which confirms the adequacy of the data collected for factorial analysis. This analysis reveals, based on the Varimax rotation, the arrangement of the scale items according to six factors that explain 52,44\% of the variance, with the appropriate items obtaining values between ,625 and ,838.

The reliability analysis of the scale confirms the high internal consistency of the instrument, obtained from the Cronbach's Alpha coefficient (,934). In addition, the two-half method obtains for the first part a value of ,884, and for the second part a value of ,910, which confirms the results obtained previously.

\subsection{Procedure and data analysis}

The access to the sample by the research team has been done from one of the compulsory subjects for each of the degrees. To this end, each academic responsible for the subject has been informed of the objective of the research, until approval has been obtained. The preference was to access the course during the scheduled teaching hours for the participating subjects to encourage student involvement and participation.

Therefore, and taking advantage of one of the theoretical classes, the scale has been presented to the sample in paper format, annexing an informative letter about the aim of the research and the instructions for the completion of the instrument. At all times, the research team has ensured the confidentiality of the data collected and the anonymity of the same.

The Statistical Package for the Social Sciences (SPSS, version 25) was used for the statistical analysis of the data collected. Firstly, a descriptive study based on the analysis of means and standard deviation has been carried out. The items that obtained the highest and lowest scores for each of the factors on the scale were highlighted. On the other hand, the Student t-test for independent samples has been used to calculate differences in means between all the items of the scale and the categorical variable: undergraduate or master students. This analysis has been calculated with a $95 \%$ confidence level.

\section{Results}

\subsection{Descriptive analysis}

Descriptive analysis of mean and standard deviation scores reveals how the highest scoring items are placed in factor 4, focusing on issues of the planning and development of the teaching-learning process Table 1 . For this factor, the favorable evaluation of the student towards the figure of the practicum tutor stands out, enhancing the coordination work between the school and the university. Similarly, it values the coherence implemented in the subjects between the development of theoretical and practical contents. At the same time, it considers that student participation is a means of improving the teaching-learning process.

The results obtained also reveal favorable scores for one of the items that form part of factor 3, centered on the study of the process of European change in the new curricula. Thus, the student is convinced that the practicum is a subject that complements the initial training received in their undergraduate and master studies.

For factor 2, focused on teaching planning, the student's positive opinion is highlighted when questioning the use, by teachers, of virtual spaces for the dissemination of materials, and the promotion of virtual teaching.

Table-1. Highest rated items on the scale.

\begin{tabular}{|c|c|c|c|}
\hline Factor & Item & $\bar{M}$ & SD \\
\hline 3 & Practicum complements my academic training & 3,94 & 1,202 \\
\hline 4 & $\begin{array}{l}\text { I consider the figure of the practicum tutor to be fundamental for a connection between the } \\
\text { school and the university }\end{array}$ & 3,91 & 1.269 \\
\hline 2 & $\begin{array}{l}\text { Teachers make good use of virtual spaces to disseminate materials and encourage virtual } \\
\text { teaching }\end{array}$ & 3,81 & 1,013 \\
\hline 4 & $\begin{array}{l}\text { In general, there is consistency between the theoretical and practical contents of the } \\
\text { subjects }\end{array}$ & 3,60 & 1.020 \\
\hline 4 & Student participation contributes to the improvement of the learning process & 3,70 & .984 \\
\hline
\end{tabular}


The descriptive analysis also gives negative results. They correspond to the items in which the average scores obtained show the student's indifference or disagreement with the propositions Table 2 . In this case, factor 5 is the one that has obtained the greatest prominence, linked to the analysis of the student's knowledge towards the degree. The student is indifferent when questioning the information received on the new study plans in higher education, both by means outside the university and by the university itself.

In turn, the remaining items with lower scores are distributed for each of the factors. It can be deduced that the student is dissatisfied with the development of subjects taught by various professors, questioning their possibilities of specialization for the degree they are studying. They are not very convinced when assessing their degree of knowledge towards the new system of credits implemented in higher education. Similarly, he questions whether the organization of university degrees will improve his training in skills, as well as the quality of higher education.

\begin{tabular}{|c|c|c|c|}
\hline Factor & Item & $\mathbf{M}$ & SD \\
\hline 2 & Subjects taught by several teachers facilitate the teaching-learning process & 2,76 & 1,257 \\
\hline 5 & $\begin{array}{l}\text { I have received information about the new higher education curricula by any } \\
\text { means outside the university }\end{array}$ & 2,82 & 1,194 \\
\hline 6 & The new curricula allow for greater specialization in my degree & 2,83 & 1,183 \\
\hline 4 & I am fully aware of the new credit system (ECTS) & 2,85 & 1,216 \\
\hline 5 & $\begin{array}{l}\text { From the university, I have been informed about the new curricula and their } \\
\text { implications for my studies }\end{array}$ & 2,91 & 1,202 \\
\hline 3 & New curricula improve skills training for university students & 2,96 & 1,023 \\
\hline 1 & $\begin{array}{l}\text { The new restructuring of degrees and master's improves the quality of } \\
\text { university education }\end{array}$ & 2,97 & 1,134 \\
\hline
\end{tabular}

\subsection{Mean differences analysis: student t-test}

The analysis of mean differences determines the existence of statistically significant differences between particular items on the scale and the categorical variable: undergraduate or master's student. Thus, the student ttest confirms the existence of more positive perceptions among the master's students in teacher training in secondary education, as compared with the students carrying out undergraduate studies in early childhood education or primary education Table 3. Students on the master's in teacher training in compulsory secondary education program are more positive when considering how the new European regulations encourage the active participation of students in the learning process $(\mathrm{t}(478)=-1,395, \mathrm{p}=, 008)$. Similarly, it evaluates the curriculum of the degree that it carries out $(\mathrm{t}(479)=-9,652, \mathrm{p}=, 002)$, having more information on its academic aspects $(\mathrm{t}(479)=-$ 7,263, $\mathrm{p}=$,039). Regarding the academic calendar, the master's student is more satisfied, considering that it facilitates learning $(\mathrm{t}(478)=-10,621, \mathrm{p}=, 000)$. Similarly, he considers that the exam calendar responds to his academic needs $(\mathrm{t}(478)=-8,891, \mathrm{p}=, 000)$, with the established number of convocations being sufficient $(\mathrm{t}(479)=-$ ,883, $\mathrm{p}=, 006)$. In addition, graduate students are more convinced that the teaching guides allow a greater knowledge of the subjects $(\mathrm{t}(475)=-5,017, \mathrm{p}=, 000)$, and the subjects taught by several professors facilitate their learning $(\mathrm{t}(479)=11,827, \mathrm{p}=, 000)$. Similarly, they are aware of the competencies inherent to the degree they are studying $(\mathrm{t}(480)=-5,928, \mathrm{p}=, 023)$ while maintaining the importance of the practicum as a complement to their academic training $(\mathrm{t}(475)=-1,605, \mathrm{p}=, 000)$ and the figure of the practicum tutor $(\mathrm{t}(478)=-2,340, \mathrm{p}=, 000)$. In addition, he thinks that the process of European convergence has meant a restructuring in the curricula capable of expanding their possibilities of specialization $(\mathrm{t}(480)=-12,502, \mathrm{p}=, 000)$.

In general, students of the master's show a more positive evaluation about the university $(\mathrm{t}(478)=-9,817$, $\mathrm{p}=, 000)$ and, more specifically and with respect to the teaching staff, towards the use of current and easily accessible bibliographical references $(\mathrm{t}(478)=-7,362, \mathrm{p}=, 002)$ and of virtual spaces $(\mathrm{t}(480)=-, 905, \mathrm{p}=, 027)$, considering that there is coherence between the theoretical and practical contents of the subjects of the degree $(\mathrm{t}(480)=-5,231, \mathrm{p}=, 002)$.

Table-3. Analysis of variance: t-test for independent samples.

\begin{tabular}{|c|c|c|c|}
\hline Items & Grade & Master & Sig. \\
\hline $\begin{array}{l}\text { The new European regulations encourage the active participation of students in the learning } \\
\text { process }\end{array}$ & 3,28 & 3,40 & ,008* \\
\hline My assessment of the curriculum of my degree is positive & 2,70 & 3,61 &, $002 *$ \\
\hline I have enough information about the academic aspects of the degree I am studying & 2,96 & 3,63 & ,039* \\
\hline The academic calendar of the degree facilitates the learning of university students & 2,55 & 3,60 & ,OOO* \\
\hline The exam schedule is tailored to my academic interests and needs & 2,53 & 3,48 & ,OOO* \\
\hline The number of examinations is sufficient & 3,02 & 3,12 & ,006* \\
\hline The teaching guides allow me to have a better knowledge of the subjects & 3,32 & 3,77 & ,OOO* \\
\hline Subjects taught by several teachers facilitate the teaching-learning process & 2,12 & 3,33 & ,000* \\
\hline I know the skills of the degree I'm taking & 3,20 & 3,73 & ,023* \\
\hline Practicum complements my academic training & 3,85 & 4,02 & ,OOO* \\
\hline $\begin{array}{l}\text { I consider the figure of the practicum tutor to be fundamental for a connection between the } \\
\text { school and the university }\end{array}$ & 3,77 & 4,04 & ,OOO* \\
\hline I believe that the new curricula allow for greater specialization in my degree & 2,67 & $4, \mathrm{OO}$ & ,OOO* \\
\hline Overall, my assessment of the university is positive & 2,93 & 3,83 & ,OOO* \\
\hline In general, teachers use current and easily accessible bibliographical references & 3,10 & 3,79 & ,002* \\
\hline $\begin{array}{l}\text { Teachers make good use of virtual spaces to disseminate materials and encourage virtual } \\
\text { teaching }\end{array}$ & 3,77 & 3,85 &, $027 *$ \\
\hline In general, there is consistency between the theoretical and practical contents of the subjects & 3,35 & 3,82 &, $002^{*}$ \\
\hline
\end{tabular}




\section{Discussion}

This research analyses the perception of university students of the bachelor's degree in early childhood, primary and secondary education towards the process of European convergence, and the introduction of the European area in initial teacher training. It is necessary to research making a balance, from a social perspective, about the process of implanting the European space in higher education in the Spanish context. This allows for the establishment of indicator maps that reflect the difficulties detected by students in this process (Radulovíc et al., 2019). As Zabalza (2016) points out, the process of European convergence has meant a modification in the conception of teaching in higher education. Therefore, it makes sense to question whether this change has meant an improvement in the quality of education in the university context.

To this end, it focuses on the student of the bachelor's degree in early childhood, primary and secondary education, understood as the future teacher. The aim is to encourage reflection among education students on the meaning and scope of this reform in their teaching-learning process. Furthermore, it is necessary to examine the teacher training process, given that it constitutes the initial phase in the development of the people on which to build the future of our society (Lüdke \& Scott, 2018). In this sense, as confirmed by Doña (2014), universities play a fundamental role in our society, being necessary for their modernization and adaptation to the European space.

On the one hand, results reveal student satisfaction with the practicum as a subject that is complementary to their academic training, with the role of the practicum tutor being relevant as a professional for establishing relations of coordination between the school in which they develop their training process and the university. Similarly, students are committed to the dissemination of materials through virtual spaces that allow for the exchange of information between teacher and student. The use of new teaching tools that enable the use of information and communication technologies and allow for a greater degree of interaction between peers is also encouraged (Ariza et al., 2013; Quevedo et al., 2015). In addition, students denote coherence between the theoretical and practical contents of the subjects in their curriculum, sustaining the importance of their participation in the teaching-learning process for the improvement of educational quality.

These results support the conclusions reached by Castano et al. (2007) and Otero et al. (2012), which reveal the positive perception of students towards the European Higher Education Area. This favors the implementation of a new educational model based on the academic and professional counseling of the student (Rodicio, 2010) founded on autonomous work, a system of continuous evaluation, personalized attention to each student through academic tutoring, decreasing the teacher-student ratio, etc. (Rodríguez, 2013).

On the other hand, students also criticize some of the implications of the European process for higher education. They show their indifference towards the development of subjects taught by several teachers, perceiving that it makes it difficult to coordinate them and to implement coordinated training actions for the students. Likewise, it reveals the scarce information received about the European space, which prevents it from knowing in depth the changes that this new process has generated in higher education. This lack of information leads to a negative evaluation of the possibilities of specialization of the degree being studied, the implications of the ECTS credit system, training in skills, or the improvement of educational quality in the undergraduate and masters study programs.

\section{Conclusion}

These results are related to those raised in previous research (Font-Mayolas \& Masferrer, 2010; Méndez, 2008; Sánchez, 2015). These studies reveal the student's denunciation towards the scarce diffusion of the information received on the changes that the European process has raised in higher education. This should be taken into consideration by university institutions since an effective implementation of the European Higher Education Area requires adequate information for students (Leo \& Cubo, 2012) in order to modify the traditional institutional and professional culture (Pérez et al., 2013).

In addition, results confirm that a student engaged in studying for a master's in teacher training in secondary education shows a more positive perception of the European convergence process. The postgraduate student values certain aspects related to the academic restructuring of the degrees more positively, the planning and organization of teaching, and the academic information of the new study plans, compared with students on the degree in early childhood and primary education course. This confirms the approach proposed by Cohen (2012), who ratifies how student satisfaction towards studies has an impact on university persistence, confirming its continuity in the university system. However, it contradicts the proposal of Hernández and Carrasco (2012), who demonstrate the dissatisfaction of students doing their master's in teacher training towards the time established for their didactic training, the link between theory and practice in the development of training programs, and the coordination between teachers.

\section{Suggestions}

This may be due to the fact that students studying for the master's and degree in teacher training have previous university training. This allows them to analyze with greater criteria the changes produced in higher education thanks to the process of European convergence, evaluating more satisfactorily the modifications incorporated in the new degrees. In addition, the high level of absenteeism and the lack of motivation and involvement of students in university classrooms should be questioned. It should be considered whether the criticisms made of this new higher education system may be due to an interest on the part of the student in obtaining an academic qualification more "easily," neglecting whether the improvements introduced have a favorable impact on their academic and professional training.

\section{Limitations}

However, the exclusive use of a scale as an instrument for data collection may generate problems such as social desirability and sincerity among participants. Therefore, with a view to future research, the intention is to expand the sample, accessing other degrees to find out the perceptions of students who are studying at universities in other 
areas of knowledge. Furthermore, it is interesting to know the perceptions of other educational agents involved in the teaching-learning process of the university system (teaching staff, administration, and services personnel, families, etc.). In this way, the aim is to assess the extent to which students' perceptions are related to the demands and concerns of others. Thus, as confirmed by Castro et al. (2006), the adaptation of the university to the European space implies a process of quality in higher education that must be translated into social guarantees.

\section{References}

Alonso-Sáez, I., \& Arandia-Loroño, M. (2017). 15 years since the bologna declaration. Development, current situation and challenges of the European higher education area. Iberoamerican Journal of Higher Education, 8(23), 199-213.

Ariza, T., Quevedo, R., Bermúdez, M. P., \& Buela, G. (2013). Analysis of postgraduate programs in the EHEA and the USA. Psychodidactic Magazine, 18(1), 197-2 19.Available at: https://doi.org/10.1387/revpsicodidact.5511.

Cabaco, A. S. (2006). Innovation in the construction of the European higher education area: London road 2007. Education Forum, 4(7-8), 119120 .

Castano, E., Capa, Á. B., Lozano, A. P., \& Jiménez, R. M. R. (2007). Impact on first-year students of the implementation of the European Area. Complutense Magazine of Education, $18(1), 199-216$.

Castro, M. A. P.-G., Trujillo, A. L., \& Merino, D. S. (2006). Spanish universities and the process of building the European higher education area: Limitations and perspectives for change. Spanish Journal of Comparative Education(12), 113-144.

Cohen, K. (2012). Persistence of master's students in the United States: Development and testinf of a conceptual model. Thesis Doctoral Dissertations. New York.

Coterón, J. (2012). Student's opinion on the implementation of the european higher education area in physical activity and sport sciences studies / students' opinion about the implementation of European higher education area in physical activity and sport sciences studies. Complutense Magazine of Education, 23(1), 191-206.

Dienel, C. (2019). Bologna-a utopy of harmony for European higher education. Innovation: The European Journal of Social Sciences, 32(4), 403405.Available at: https://doi.org/10.1080/13511610.2019.1674131.

Doña, L. (2014). Marketing and university analysis from the perspective of the graduate. Thesis Doctoral Dissertations: University of Granada.

Esia-Donkoh, K., \& Baffoe, S. (2018). Instructional supervisory practices of headteachers and teacher motivation in public basic schools in anomabo education circuit. Journal of Education and e-Learning Research, 5(1), 43-50.

Expósito Langa, M., Tomas Miquel, J. V., \& Torres Gallardo, G. (2012). Perception and knowledge of university students of business administration and management about the European Higher Education Area (EHEA). Complutense Magazine of Education, 23(1), 265-283.Available at: https://doi.org/10.5209/rev_rced.2012.v23.n1.39114.

Font-Mayolas, S., \& Masferrer, L. (2010). Knowledge and attitudes of university students regarding the European higher education area. Journal of Training and University Educational Innovation, 3(2), 88-96.

Galán, A. (2012). The effects of the implementation of the EHEA in the evaluation of teaching competence in Spain. Catalan Journal of Public Law, 44(1), 349-370.

Gibbs, L. (2012). Persistence of graduate students at an urban research institution in the Southeastern region of the United States. Thesis Doctoral Dissertations. Clark Athlanta University.

Hauschildt, K., Gwosć, C., Netz, N., \& Mishra, S. (2015). Social and economic conditions of student Life in Europe. Synopsis of indicators. In eurostudent V 2012-2015. Bielefeld: W: Bertelsmann Verlag.

Hernández, M. J., \& Carrasco, V. (2012). Perceptions of thestudents of the master in teacher training in secondary education: strengths and weaknesses of the new training model. Teaching \& Teaching: Interuniversity Journal of Didactics, 30(2), 127-152.

Jarvis, P. (2006). Corporate universities: New learning models in the global society. Madrid: Narcea.

Klemenčič, M. (2019). 20 years of the bologna process in a global setting: the external dimension of the bologna process revisited. European Journal of Higher Education, 9(1), 2-6.

Leo, M., \& Cubo, S. (2012). The European space of higher education. Attitudes ofthe students of the university of extremadura. Open Field, $31(1), 29-50$.

Lüdke, M., \& Scott, D. (2018). The place of the internship in teacher education in two perspectives: Brazil and England. Education E̊ Society, $39(142), 109-125$.

Méndez, R. M. (2008). Young university students and their (dis) orientation towards the new challenges posed by EEES. Education XXI Century, 26(1), 197-224.

Meyer, J., \& Ramírez, F. (2002). The global institutionalization of education. In Jürgen Schriewer (comp.) Discourse formation in comparative education (pp. 91-111). Barcelona: Orchards Editions.

Migdadi, A. I. M., \& Baniabdelrahman, A. (2016). The effect of using team teaching on Jordanian EFL eleventh grade students' reading comprehension and their attitudes towards this strategy. Journal of Education and e-Learning Research, 3(2), 38-50.Available at: https://doi.org/10.20448/journal.509/2016.3.2/509.2.38.50.

Mingorance, E. A. C., Granda, V. J., Rojas, R. G., \& Alemany, A. I. (2019). Flipped classroom to improve university student centered learning and academic performance. Social Sciences, 8(11), 1-14.Available at: https://doi.org/10.3390/socsci8110315.

Montes, D. A., \& Suárez, C. I. (2016). University teacher training: Training keys of Spanish universities. Electronic Journal of Educational Research, $18(3), 51-64$.

Mora, J. G. (2004). The need for educational change for the knowledge society. Iberoamerican Magazine of Education, 35(1), $13-37$.

Oosterlinck, A. (2013). Accountability, the history of Magna Universitatum and the Bologna Declaration (pp. 41-52). Porland: Press Limited.

Otero, C., Ferro, C., \& Vila, M. (2012). Student satisfaction with the implementation of the EHEA model. Comparative analysis. Digital Educational Magazine, $12(1), 35-42$.

Pegalajar, M. C. (2016). European convergence process evaluation from the perspective of master`s degree programme for secondary education students. Iberoamerican Journal of Educational Evaluation, 9(2), 65-80.

Pérez, M., Quijano, R., \& Ocaña, M. T. (2013). University teachers facing the European higher education area: Two years later. Education Century XXI, 31(2), 235-254.

Quero, V. D. (2006). Teacher training, pedagogical practice and pedagogical knowledge. Laurus, 12(Ext), 88-103.

Quevedo, R., Ariza, T., \& Buela, G. (2015). Assessment of science teachers' satisfaction with the adaptation to the European higher education area. Educación XX1,18(1), 45-70.

Radulovíc, B., Gajic, O., Spanovic, S., \& Lungulov, B. (2019). Challenges of initial teacher education in the context of higher education reform in Serbia. Education and Self Development, 14(3), 34-39.Available at: https://doi.org/10.26907/esd 14.3.04.

Rivas, J. I. (2016). Teacher work, knowledge and social change. Journal of the School of Education Sciences, 5, 31-47.

Rodicio, M. L. (2010). The university teaching in the process of adjustment to Europe: The perception of the students. Teaching \& Teaching, $28(2), 23-43$.

Rodríguez, R. (2013). Professors' perceptions of the training model in the European higher education area. A case study. Journal of Research in Education, $11(2), 226-224$.

Sánchez, A. M. (2015). Students' perceptions of the European convergence process. European Journal of Child Development, Education and Psychopathology, 3(2), 69-79.Available at: https://doi.org/10.30552/ejpad.v3i2.30.

Santos, A. I., \& Serpa, S. (2020). Flipped classroom for an active learning. Journal of Education and E-Learning Research, 7(2), $167-173$.

Soilemetzidis, I., Bennett, P., \& Leman, J. (2014). The postgraduate thaught experience survey. Hesligton York: The Higher Education Academic.

Tezci, E. (2017). Adaptation of ATI-R scale to Tukish Samples: Validity and reliability analyses. International Education Studies, 10(1), 6781.Available at: https://doi.org/10.5539/ies.v10n1p67.

Vaillant, D. (2010). The teaching identity. The importance of teachers. Educational Neres Magazine, 22(234), 1-17. 
Vallejo, M., \& Molina, J. (2011). Analysis of active methodologies in the master's degree in early childhood education: students' perspective. Interuniversity Electronic Journal of Teacher Training, 14(1), 207-217.

Vallet-Bellmunt, T., Rivera, P., Vallet-Bellmunt, I., \& Vallet-Belmunt, A. (2017). Cooperative learning, perceived learning and academic achievement in teaching Marketing. Educación XX1, 20(1), 277-297.

Vazirani, S., Carmona, C., Hernaiz, N., \& Shuali, T. (2019). The impact of international stays on the development of competences in phd students and their transfer in different contexts. Publicaciones, 49(1), 79-91.

Wilkins, S., Butt, M., Kratochvil, D., \& Balakrishnan, M. (2016). The effects of social identification and organizational identifi cation on student commitment, achievement and satisfaction in higher education. Studies in Higher Education, 41 (12), $2232-2252$.

$\mathrm{Xu}$, Y. J. (2014). Advance to and persistence in graduate school: Identifying the influential factors and major-based differences. Journal of College Student Retention, $16(3), 391-417$.

Zabalza, M. A. (2016). Be a university professor today. The University Question, 5(1), 68-80. 